MATEUSZ RODAK

\title{
NIELEGALNY HAZARD W II RZECZYPOSPOLITEJ REKONESANS BADAWCZY
}

Niniejszy tekst jest próbą zmierzenia się z fenomenem hazardu w II Rzeczypospolitej, który stanowił znaczący element szeroko rozumianej sfery dotyczącej rozrywki czy w ogóle życia społecznego. Przez „hazard” rozumiem gry, w których o wygranej decyduje los, a nie umiejętności graczy, tj. ruletkę, grę na wyścigach, w pokera, tzw. kiszkę (hazardowa odmiana domina) oraz kości. Granice pomiędzy tym, co jest gra hazardowa, a co nią nie jest, jak zauważył Adam Podgórecki, pozostaja płynne. Istotnym momentem identyfikacyjnym jest postawa (odczucia) samego gracza. Podgórecki zaznaczał przy tym, że w pojęciu hazardu łaczą się trzy elementy: 1. subiektywne inklinacje graczy; 2. „hazard jest kultywowany i rozprzestrzenia się wskutek psychicznej zaraźliwości w swoistej podkulturze melin, kasyn gry, rozmaitych sekretnych salonów itp.”; 3. „hazard jest swoistym rodzajem aktywności, która może być wykorzystana przez rozmaite instytucjonalne ekspozytury nastawione na ciagnięcie zysku z tego rodzaju dewiacyjnych inklinacji”".

Istotne wydaje się również inne rozróżnienie, na które już wówczas szczególnie zwracano uwagę, a mianowicie podział na „grę hazardową” oraz „grę oszukańczą". W podręczniku Stużba śledcza. Podręcznik dla organów bezpieczeństwa z 49 rycinami czytamy: „Oszustwa karciane zdarzają się bardzo często. W tym typie oszustwa odróżnić musimy grę hazardową od gry oszukańczej. Pierwsza opiera się przynajmniej na pewnym obliczaniu, druga zaś nie jest niczym innym jak tylko oszustwem uprawianym wprost zawodowo. Od hazardowej do oszukańczej

\footnotetext{
${ }^{1}$ A. Podgórecki, Patologia życia społecznego, Warszawa 1969, s. 166 n.
} 
gry jest już tylko mały krok"2. W tym przypadku kluczową rolę odgrywała postawa oszusta (szulera) manipulującego pozostałymi graczami. Naturalnie gra traciła w takiej sytuacji cechy gry hazardowej.

Problematyce nielegalnego hazardu w II Rzeczypospolitej autor niniejszego opracowania zamierza się przyjrzeć na przykładzie Warszawy. Stolica jako duży ośrodek miejski kumulowała w sobie wszystkie patologie życia społecznego, w tym wyraźnie zaznaczający się i łatwo uchwytny dla badacza nielegalny hazard. Pozostawała również wzorem dla pozostałych miast Polski. Tekst ten jest rekonesansem badawczym, propozycja określenia podstawowych cech zjawiska, postawieniem pytań i otwarciem dyskusji nad niezbadanym jeszcze elementem życia społecznego Polski lat 1918-1939.

W przypadku osób skazanych, których dane pojawiały się wyłącznie w aktach policyjnych, używać będę inicjałów nazwisk. W przypadku skazanych, których dane upublicznione zostały w międzywojennej prasie, zasada ta nie będzie stosowana.

\section{Sytuacja prawna hazardu w II Rzeczypospolitej}

W okresie międzywojennym nie istniało rozporządzenie czy ustawa regulujące kwestię hazardu w całości. Hazard był legalny jedynie w bardzo waskim zakresie. W II RP obowiazywały dwie ustawy regulujacce te formy hazardu, do których wyłączne prawo zagwarantowało sobie państwo. Mowa tu o ustawie z 26 III 1920 r. w przedmiocie urzadzania loterii i założenia Polskiej Państwowej Loterii Klasowej ${ }^{3}$, zmienionej w 1936 r. $^{4}$, oraz ustawie z 22 VI 1925 r. o wyścigach konnych ${ }^{5}$. Pierwsza z nich powoływała do życia Polską Państwową Loterię Klasowa (od 1936 r. Polski Monopol Loteryjny) nadzorującą loterię, która pozostawała państwowym monopolem, tak jak wszystkie zresztą organizowane na terenie Polski gry loteryjne. Każda loteria musiała być zatwierdzona przez rząd i urządzana mogła być tylko na cele dobroczynne lub użyteczności publicznej. Ustawa zakładała również możliwość, za zgoda państwa, organizowania loterii fantowych. Urządzenie loterii bez odpowiednich pozwoleń traktowane było jako wykroczenie karno-

${ }^{2}$ W. Stepek, Z. Hoffman Krystyańczyk, Stużba śledcza. Podręcznik dla organów bezpieczeństwa z 49 rycinami, Poznań 1923, s. 202.

${ }^{3}$ Dz. U. 1920 , nr 31, poz. 180 , s. $482-483$.

${ }^{4}$ Dz. U. 1936, nr 55, poz. 397-398, s. 886-888.

${ }^{5}$ Dz. U. 1936, nr 79, poz. 551-552, s. 1295-1296. 
-skarbowe i jako takie karane ${ }^{6}$. Druga z ustaw regulowała zasady organizowania wyścigów konnych, na które pozwolenia wydawało Ministerstwo Rolnictwa i Reformy Rolnej. Ustawa określała również kwestie odpowiedzialności karnej za nielegalne urządzanie wyścigów konnych. Wszelkie formy uprawiania hazardu, inne niż wyścigi konne lub państwowe loterie, były zakazane. Pod koniec lat trzydziestych pojawił się pomysł, aby na Polach Mokotowskich urządzać legalne wyścigi psów ${ }^{7}$.

W międzywojennej Polsce nie było legalnych domów gry. Najbliższe kasyno z prawdziwego zdarzenia działało od 1920 r. w Sopocie. W Polsce istniały tzw. kasyna oficerskie czy urzędnicze, nie miały one jednak nic wspólnego z profesjonalnymi domami gry. Były to elitarne miejsca, do których wstęp mieli tylko uprzywilejowani, gdzie można było w gronie znajomych zjeść, przejrzeć prasę, pograć w szachy, ewentualnie w brydża czy pokera, czasem nielegalnie na pieniądze. W Warszawie kasyna oficerskie mieściły się na rogu ul. Szopena i Alei Ujazdowskich w tzw. kamienicy Spokornego, Ułańskiej, w Sztabie Generalnym, na pl. Saskim pod nr 7, w Zamku Królewskim oraz na terenie Cytadeli, kasyno urzędnicze zaś przy Nowym Świecie $67^{8}$.

Hazard, z wyjątkiem wyścigów konnych i loterii państwowych, był według prawa wykroczeniem. Po I wojnie światowej, w obowiązującym po 1918 r. na terenie byłego Królestwa Polskiego kodeksie z 1903 r., osoba, która urządzała zabroniona przez ustawę grę lub udostępniała w tym celu lokal, podlegała karze grzywny do 20 tys. marek polskich (wysokość grzywny obowiązująca po 1918 r.), otwarcie natomiast domu gry karane było więzieniem i karą pieniężną w wysokości 120 tys. marek polskich ${ }^{9}$. W kodeksie karnym, zmodyfikowanym w latach dwudziestych, obowiązującym do początku następnej dekady, czytamy w art. 289: „Winny urządzania gry w karty, w kości itp. zabronionej przez ustawę lub rozporządzenie obowiązujące, albo oddania na taka grę swojego pomieszczania, będzie karany aresztem lub grzywną do 1000 zł. (Sądy

${ }^{6} \mathrm{~W}$ listopadzie 1933 r. przekonał się o tym prezes Towarzystwa Wyścigów Konnych hr. Michał Komorowski, który patronował pewnej imprezie. W jednym ze stołecznych dzienników czytamy: „Chodziło o imprezę zorganizowaną przez impresaria Iwanowskiego, który urządził rewię mód połączoną z loterią fantową w której udział brali nabywcy programów wyścigowych zaopatrzonych w odpowiednią numerację. Nagrody były wartości od trzech do 500 zł". Sąd skazał hr. Komorowskiego na 1 dzień aresztu; Prezes Towarzystwa Wyścigów Konnych hr. Komorowski skazany na 1 dzień aresz$t u$, „Nasz Przegląd” 1933, nr 302, s. 10.

${ }^{7}$ Psie wyścigi w Warszawie, „Gazeta Warszawska” 1828, nr 229, s. 8.

${ }^{8}$ Przewodnik po Warszawie, Warszawa 1923, s. 127.

${ }_{9}^{9}$ N. Tagancew, Kodeks karny (22 marca 1903 r.), tłum. L. Konic, t. 3, Warszawa 1922, s. 271. 
Pokoju). Jeśli winowajca otworzył dom gry zabronionej, będzie karany zamknięciem w więzieniu, a nadto karą pieniężną do $6000 \mathrm{z}$ ”"10. W nowym kodeksie z 1932 r. artykuł traktujący o nielegalnym hazardzie znalazł się w dołączonym do kodeksu rozporządzeniu prezydenta: Prawo o wykroczeniach, gdzie w art. 61 czytamy: „§ 1 Kto w celu zysku urządza grę hazardowa, albo użycza do niej środków lub pomieszczenia podlega karze aresztu do 3 miesięcy i grzywny do 3000 złotych. § 2 Pieniądze i inne przedmioty służące do gry podlegaja przepadkowi"11. W komentarzu do tego artykułu autor wyjaśniał, co należało rozumieć pod pojęciem hazardu: „Hazard - polega na tym, że uzależnia wygraną lub przegrana wyłącznie lub przeważnie od wypadku losowego. Pewna niewielka doza kombinacji nie pozbawia gry charakteru hazardowego, gdy przeważną rolę odgrywa los. Nie podlegają zatem pojęciu hazardu gry, w których wyłączną lub przeważną rolę przypisać należy umiejętności gracza (piłka, szachy, brydż) albo gry oszukańcze. Karze według tego art. podlegaja gry tylko w celu zysku urządzane. Karze ulegnie także użyczający pomieszczenia, np. lokalu zamkniętego lub otwartego, środków jak np. kart, choćby udziału w samej grze nie brał. Użyczający lokalu lub środków nie musi odnosić korzyści z urządzanej gry hazardowej"12.

Karze podlegały nie tylko wspomniane wyżej czynności. Odpowiedzialność karną ponosiła również osoba, która bez zezwolenia Ministerstwa Rolnictwa i Reformy Rolnej urządzała wyścigi konne oraz ta, która: „Ofiarowuje zakład lub bierze udział albo pośredniczy w zakładach urządzanych wbrew przepisom art. 5 ust. 1 i 2 , a pozostających w związku z wyścigami konnymi" ${ }^{13}$. Osobom łamiącym te przepisy groziło do trzech miesięcy więzienia i/lub grzywna do 3 tys. zł kary (prawo obowiąujące od $1925 \mathrm{r}$. $)^{14}$.

W byłym zaborze pruskim, gdzie - do momentu ujednolicenia prawa w 1932 r. - obowiazywał niemiecki kodeks karny z 1871 r., urządzanie nielegalnych gier hazardowych traktowane było jako wykroczenie ${ }^{15}$. Za

${ }^{10}$ A. Mogilnicki, E.S. Rappaport, $K K z$ ustawami dodatkowymi wydanymi do dnia 1 września 1927 r., Warszawa 1928, s. 263.

${ }^{11}$ K. Sobolewski, A. Laniewski, Polski KK z 11.07.32 r. wraz z prawem o wykroczeniach, przepisami wprowadzajacymi $i$ utrzymanymi $w$ mocy przepisami KK austriackiego, niemieckiego, rosyjskiego i skorowidzem, Lwów 1932, s. 182.

${ }_{12}$ Tamże.

${ }^{13}$ Dz. U. 1936, nr 79, poz. 551-552, s. 1296.

${ }^{14}$ Tamże.

${ }^{15}$ Kodeks Karny Rzeszy Niemieckiej z dnia 15 maja 1871 r. z późniejszymi zmianami i uzupetnieniami po rok 1918 wraz z ustawa wprowadza do kodeksu karnego dla Zwiazku Pótnocno-Niemieckiego (Rzeszy Niemieckiej) z dnia 31 maja 1870 r., Poznań 1920, s. 146. 
organizowanie gier hazardowych w miejscach publicznych groziły kary aresztu lub grzywny ${ }^{16}$. W austriackim kodeksie z $1852 \mathrm{r}$. nielegalnym grom hazardowym poświęcony był paragraf 522, w którym za urządzanie takich gier przewidywano stosowne kary grzywny ${ }^{17}$. Tu również organizowanie nielegalnego hazardu było tylko wykroczeniem.

\section{Formy hazardu w II Rzeczypospolitej}

Najprostszą próbą klasyfikacji gier hazardowych będzie podział na legalne i nielegalne. Granicę legalności wyznaczała w II RP kontrola państwowa. W tej sytuacji nielegalnymi formami hazardu stawały się również urządzane bez właściwych pozwoleń loterie i wyścigi. Najpopularniejsza gra hazardową pozostawała gra w karty (przede wszystkim w pokera i bakarata).

W karciane gry hazardowe (poker, oczko, blackjack) na pieniądze grywano wszędzie, zarówno na salonach (w kasynach oficerskich, pałacach ziemiańskich), jak i w złodziejskich melinach czy celach więziennych. Popularność tej formy hazardu wynikała z wielu przyczyn. Karty pozostawały rekwizytem dostępnym powszechnie, tanim, łatwym do ukrycia, niesprawiającym problemów w czasie transportu, a przede wszystkim możliwym do wykorzystania wszędzie i w każdej sytuacji. W czasie obławy policyjnej karty można było dużo łatwiej ukryć niż ciężkie i duże zazwyczaj ruletki. Zresztą zakazana była tylko hazardowa gra w karty, a to nie zawsze można było udowodnić.

Dużą popularnością cieszyła się również gra w kości, które stanowiły poręczny i dość bezpieczny (łatwy do ukrycia) rekwizyt. Kości jednak w odróżnieniu od kart jednoznacznie kojarzone były z hazardem. Wymagały również dodatkowych akcesoriów (np. kubki, trwałe podłoże), co znacznie utrudniało zorganizowanie gry np. w podróży. Stąd być może w czasie badań nad zjawiskiem nielegalnego hazardu w międzywojennej Warszawie ten rodzaj gry hazardowej spotykany był dość rzadko. Niemniej jednak gra w kości pozostawała trwałym elementem międzywojennych targowisk, jarmarków czy bazarów.

Kolejna rozrywka, popularna w warszawskich kasynach „drugiej klasy", była gra w tzw. kiszkę, czyli hazardową odmianę domina. Polegała ona na losowym dobieraniu kolejnych klocków i bądź to układaniu,

16 Tamże, s. 144, 146.

${ }^{17} \mathrm{http}: / /$ de.wikisource.org/wiki/Strafgesetz_1852_(\%C3\%96sterreich)\#.C2. A7._517._Betteln (17 XI 2011). 
jak w klasycznej grze w domino, bądź tworzeniu (jak w pokerze) odpowiednich figur. Z zachowanych dla Warszawy źródeł policyjnych i prasowych wynika, że domino pozostawało gra niezwykle popularna, niewiele w tym ustępujac kartom.

Zorganizowanie gry $\mathrm{w}$ ruletkę wymagało ze strony organizatorów wielu nakładów: czasowych, lokalowych i finansowych. Ówczesne ruletki, różnych rozmiarów - od małych, „podręcznych” po duże, stosowane w kasynach - najczęściej wyrabiane były chałupniczo (oczywiście nielegalnie), rzadziej sprowadzano je z zagranicy. Niezbędnymi rekwizytami były sztony, stoły (lub kartony) do obstawiania, kulki. Organizator ruletki musiał zatrudniać zawodowych krupierów. Wszystko to sprawiało, że „królowa kasyn” pozostawała w ówczesnej Polsce elitarna gra hazardowa, do której dostęp był ograniczony. Grywano w ruletkę zazwyczaj w prywatnych mieszkaniach, rzadziej w wynajętych pokojach hotelowych, ale też $\mathrm{w}$ specjalnie przystosowanych pomieszczeniach w restauracjach bądź kawiarniach.

Dużym zainteresowaniem cieszyły się działające poza kontrolą państwowa zakłady bukmacherskie, w nomenklaturze policyjnej zwane kantorami, w których można było obstawiać m.in. wyścigi konne ${ }^{18}$. Zazwyczaj urządzano je w kawiarniach, rzadziej w prywatnych mieszkaniach. Do zorganizowania przenośnego kantoru wystarczały: niewielki stolik, kasetka z pieniędzmi, kilka kartek i krzesło. 27 V 1936 r. w prywatnych mieszkaniach przy ul. Złotej i Zielnej wywiadowcy Urzędu Śledczego zlikwidowali dwa kantory, gdzie przyjmowano zakłady pieniężne na nielegalny totalizator i wyścigi konne ${ }^{19}$. Jednocześnie zakwestionowano w czasie rewizji: bloczki, programy wyścigowe, kartki z notatkami oraz pieniądze - w sumie $17 \mathrm{zł}^{20}$. Sama więc gra miała miejsce dopiero na torze wyścigowym, gdzie gracze przenosili się z kantorów, w których porobili zakłady.

W okresie międzywojennym można było również uprawiać hazard, wykorzystujacc $\mathrm{w}$ tym celu tzw. maszyny zręcznościowe, które zaczęły się pojawiać w II Rzeczypospolitej w latach dwudziestych. Najpopularniejszym z tych urządzeń było „Bajazzo” (,The Clown”, „Pajac”, produkcji niemieckiej, rozmiary najczęściej spotykanego w latach dwudziestych w Niemczech modelu: 42,5 x 15 x 63,2 cm, produkowane od

${ }^{18} \mathrm{~W}$ czasie prowadzonej kwerendy archiwalnej i prasowej nie spotkałem się z innymi przykładami możliwych zakładów, np. sportowych, politycznych etc. Oczywiście, nie oznacza to, że ich nie było.

${ }^{19}$ AP m.st. Warszawy, Komenda Policji Państwowej m.st. Warszawy (dalej: KPP m.st. Warszawy), sygn. 372, Zgłoszenia sytuacyjne, 1936, s. 127.

${ }^{20}$ Tamże. 
1907 r.), w którym wrzucona moneta (żeton), odbijając się od wbitych gwoździ, wpaść powinna do poruszającego się pod nimi poziomo pojemnika w kształcie pajaca. Gracz nie miał wpływu na poruszający się pojemnik. Moneta, która wpadała do pojemnika, uruchamiała system wypłacający wygraną ${ }^{21}$.

W drugiej połowie lat dwudziestych Ministerstwo Spraw Wewnętrznych rozpoczęło akcję likwidacji placówek, które zarabiały, utrzymując automaty. Pierwsze zalecenia MSW pojawiły się 7 II 1927 r., kiedy to zwrócono „uwagę na rozpowszechnienie się w ostatnich czasach hazardowej gry pieniężnej przy pomocy aparatu «Bajazzo», względnie «Rigoletto», która ze względu na niskie stawki i silne emocje wciaga do gry sfery najuboższe, a przede wszystkim młodzież, działając w ten sposób demoralizująco i szkodliwie"22. Nakazano policji skrupulatny nadzór nad wszystkimi lokalami, w których podawany był alkohol i w razie stwierdzenia gry na tych aparatach, nakazywanie właścicielom bezzwłocznego usuwania ich z głównych $\mathrm{sal}^{23}$. W rozkazie z listopada $1927 \mathrm{r}$. komendant stołecznej policji donosił, że wspomniane urządzenia najczęściej ustawiane były w warszawskich kinoteatrach, przede wszystkim w „Colosseum”, „Palace” i „Tomboli”24. Rok później (grudzień 1928 r.) MSW (z pełnym poparciem Ministerstwa Sprawiedliwości) wydało rozporządzenie porządkowe dotyczące tzw. aparatów zręcznościowych ${ }^{25}$.

W rozporządzeniu, które przesłane zostało do wszystkich województw, MSW wyrażało swój niepokój, stwierdzając, że wspomniane urządzenia są „dla każdego dostępną szkołą hazardu”, a jednocześnie przyczyniają się do demoralizacji młodzieży, ludności rzemieślniczej, robotniczej oraz włościańskiej ${ }^{26}$. Jak wynika z treści dokumentu, aparaty zaopatrzone były w informacje o szkodliwości ich działania. Pomimo tego ministerstwo miało wątpliwości, stwierdzano bowiem, że „napisy jakoby mające złu temu zapobiec $\mathrm{w}$ rzeczywistości wywierają skutek wręcz przeciwny”. W związku z tym autorzy rozporządzenia wymagali od wojewodów i podległych im służb, by podjęto działania zmierzające do usunięcia istniejących już aparatów z miejsc publicznych (dworce ko-

${ }^{21} \mathrm{http}: / / \mathrm{www}$.automatix-club.de; w internecie dostępne są strony poświęcone kolekcjom maszyn do uprawiania hazardu. Większość z nich to strony niemieckie, z bardzo bogatymi zbiorami fotografii.

${ }^{22}$ AP m.st. Warszawy, KPP m.st. Warszawy, sygn. 15, Rozkazy Komendanta PP m.st. Warszawy od nr 201 do 351, 1927, rozkaz 215, s. 29.

${ }^{23}$ Tamże.

${ }^{24}$ Tamże, s. 254.

${ }^{25}$ AAN, Ministerstwo Spraw Wewnętrznych (dalej: MSW), sygn. 691, Rozporządzenia porządkowe, s. 770 .

${ }^{26}$ Tamże. 
lejowe, kawiarnie, parki i place miejskie, kina, lokale rozrywkowe itp.) i niewydawania pozwoleń na ustawianie kolejnych ${ }^{27}$. Efektów podjętych działań nie można niestety ocenić.

\section{W warszawskich szulerniach okresu międzywojennego}

Zachowany materiał źródłowy dla Warszawy przynosi wiele informacji dotyczących miejsc, w których policja dokonywała obław na nielegalne kasyna czy zakłady bukmacherskie. Niestety, dostępne źródła policyjne obejmuja swoim zasięgiem jedynie obszar Śródmieścia - tylko dla tej bowiem dzielnicy Warszawy się zachowały. Niemniej jednak wyłania się z nich pewien obraz nielegalnego hazardu i warszawskiego świata graczy. Z drugiej strony, analiza prasy potwierdza dominującą rolę tej części Warszawy. Nielegalne szulernie poza Śródmieściem były wyjątkiem. Na ponad 60 konkretnych lokalizacji hazardu zaledwie kilka miejsc znajduje się poza Śródmieściem (głównie na Woli). Szczególną popularnością cieszyły się okolice Dworca Głównego, ul. Marszałkowska (przede wszystkim jej część biegnąca na południe od Alei Jerozolimskich) oraz Nalewki. Nie oznacza to oczywiście, że pozostałe dzielnice Warszawy, w tym przede wszystkim Praga, pozostawały wolne od nielegalnego hazardu. Wydaje się, że dominacja Śródmieścia wynikała z dwóch co najmniej przyczyn. Po pierwsze, znacznie bardziej niż w innych dzielnicach nasilonej inwigilacji policji, a więc większej wykrywalności, po drugie zaś, ze względu na to, że w tym rejonie dominowały duże lokale, w których grywano w ruletkę lub w karty w większych grupach, a np. na Pradze, gdzie również uprawiano hazard, grywano okazjonalnie, przede wszystkim w karty lub kości. Poza tym do lokali w centrum miasta częściej trafiały osoby przypadkowe, zazwyczaj przyjezdni, którzy straciwszy sporo gotówki, po pechowej grze spieszyli donieść o tym na komisariat. To zresztą na ten typ klientów liczono najbardziej, a najlepszą lokalizacją w takiej sytuacji wydawało się ścisłe centrum miasta.

Miejsca, w których można było nielegalnie zagrać w Warszawie, podzielić można na dwie kategorie: kantory bukmacherskie i tzw. domy hazardowe (zwane również: ruleciarniami, kasynami, domami gry czy szulerniami).

W międzywojennej Warszawie wskazać można kilka lokalizacji, gdzie, pomimo kolejnych policyjnych nalotów, stale funkcjonowały pręż-

${ }^{27}$ Tamże, s. 771. 
nie działające zakłady bukmacherskie i/lub kasyna. Największe przywiazanie do miejsc wykazywały, łatwiejsze do zorganizowania, nielegalne zakłady bukmacherskie. Bardzo popularna wśród organizatorów tego typu „lotnych kantorów” była ul. Marszałkowska. Między innymi w ciagu sześciu dni we wrześniu 1936 r. policja zlikwidowała kantor przy ul. Marszałkowskiej 90 oraz pod numerem 14, urządzony w prywatnym mieszkaniu, gdzie zatrzymano dziesięciu graczy oraz zakwestionowano: bloczek bukmacherski, trzy programy wyścigów, 12 kartek z notatkami oraz 32 zł gotówką ${ }^{28}$. W mieszczącej się przy ul. Marszałkowskiej cukierni Kleszcza można było obstawiać biegi koni na wyścigach organizowanych w Zakopanem ${ }^{29}$. 8 II 1934 r. aresztowano tam 30 bukmacherów, którzy kontaktując się z Zakopanem telefonicznie, przyjmowali nielegalne zakłady ${ }^{30}$. Bardzo dużym powodzeniem cieszyła się również ul. Nowogrodzka, przy której przez cały 1936 r. działały nieprzerwanie trzy zakłady bukmacherskie ${ }^{31}$. Lotne kantory działały również tam, gdzie było na nie największe zapotrzebowanie, tj. w okolicach i na samym torze warszawskich wyścigów konnych. Policja jedynie we wrześniu 1936 r. zlikwidowała aż cztery tego typu miejsca, z których trzy prowadzone były przez Żydów, jeden zaś przez Polaka ${ }^{32}$. O tym jak bardzo było to powszechne zjawisko świadczy m.in. to, że w analizowanym tu miesiacu, tj. wrześniu 1936 r., w całej Warszawie zlikwidowano 11 kantorów.

Przykrywki dla nielegalnych kasyn dostarczały często lokale gastronomiczne oraz klubowe. W nocy z 12 na 13 IX 1936 r. w lokalu Klubu Stowarzyszenia Wzajemnej Pomocy Komiwojażerów m.st. Warszawy przy ul. Leszno $14 \mathrm{w}$ czasie policyjnej kontroli zastano prawie 50 osób grających w karty na pieniądze. Tylko 22 osoby należały do klubu ${ }^{33}$. W grudniu 1938 r. policja zlikwidowała, inwigilowany od wielu miesięcy, dom hazardowy ${ }^{34} \mathrm{w}$ herbaciarni przy ul. Pańskiej, należącej do Jankla F. - „znanego międzynarodowego złodzieja kieszonkowego”. Policja po wejściu do herbaciarni zastała przy stołach z ruletkami 59 osób „rekrutujących się ze sfer przestępczych, notowanych w kartotekach tut.

${ }^{28}$ AP m.st. Warszawy, KPP m.st. Warszawy, sygn. 372, Zgłoszenia sytuacyjne, 1936, s. 215,220

${ }^{29}$ Obława na bookmacherów, „Gazeta Polska” 1934, nr 40, s. 10.

${ }^{30}$ AP m.st. Warszawy, KPP m.st. Warszawy, sygn. 372, Zgłoszenia sytuacyjne, 1936, s. 215,220 .

${ }^{31}$ Tamże, s. 226.

32 Tamże, s. 216-217.

${ }_{33}$ Tamże, s. 223.

${ }^{34}$ AP m.st. Warszawy, KPP m.st. Warszawy, sygn. 374, Komunikaty sytuacyjne, 1937-1938, s. 605. 
Urzędu za kradzieże, oszustwa, terror i komunizm. Trzech z nich: [...] jest poszukiwanych listami gończymi, 25 pozostałych notowanych" 35 . Znacznie więcej, bo aż 79 grających osób udało się zatrzymać policji w czasie likwidacji w styczniu 1939 r. kasyna mieszczacego się „w obszernych salach baru «Wersal» przy ul. Elektoralnej”36.

Jedna $\mathrm{z}$ form ochrony przed działaniami policji było przenoszenie nielegalnych domów gry. Ich organizatorzy, unikając w ten sposób policyjnego najścia, przenosili niezbędne do gry akcesoria z miejsca na miejsce, wcześniej oczywiście informujac o tym graczy.

W styczniu 1925 r. w „Polsce Zbrojnej” ukazała się lakoniczna notatka o wykryciu przez policję „nowej spelunki gry”, gdzie „,jeden z grających w chwili aresztowania przegrał w karty przeszło 100 miliardów marek [tj. około 11 tys. dolarów, co wydaje się kwotą dość znaczna M.R.]" ${ }^{37}$. W następnym numerze podano szczegóły. Właścicielami lotnych domów gry byli, znani policji, warszawscy szulerze karciani oraz współpracujący z nimi kasjerzy i krupierzy. Ośmioosobowa szajka, działająca od wielu miesięcy, składała się z mieszanego narodowościowo towarzystwa: szulerami byli Polacy, a Żydzi pełnili rolę kasjerów i krupierów. Lokale, które zamknęła policja, mieściły się na ul. Nowogrodzkiej i Szopena. Tak opisywano specyfikę działania szajki: „Spelunka ta należała do kategorii lotnych domów gry, których właściciele utrzymali cały sztab eleganckich ustosunkowanych młodzieńców, dostarczajacych klubom coraz to nowe ofiary. Młodzież owa brała udział w grze naturalnie za pieniądze przedsiębiorców, podbijała stawki, a jeśli wygrywała, to pieniądze wracały do kieszeni przedsiębiorcy. Fałszerstwo przy tym opierało się głównie na ułożonych z góry taliach lub wzajemnym porozumieniu oszustów. Poza tym przedsiębiorca pobierał od gry wysoki procent wynoszący od 6 do 10 miliardów [tj. od około 650 do 1000 dolarów - M.R.]. W zamian za to zabezpieczał grajacych przed ewentualnym najściem policji i opłacał honoraria dla specjalnych straży, czuwających nad domem"38. Organizatorzy zapewniać mieli grajacym posiłki oraz „panie do towarzystwa”, za które należało wnosić

${ }^{35}$ Tamże.

${ }^{36}$ AP m.st. Warszawy, KPP m.st. Warszawy, sygn. 375, Komunikaty sytuacyjne, 1939, s. 180.

${ }^{37}$ Można przypuszczać, że autor artykułu przedstawiał wydarzenia z końca $1924 \mathrm{r}$. Wskazuje na to użycie w informacji o skali zakładów marek polskich, które w połowie 1924 r. zostały wycofane z obiegu, niemniej jednak przez jakiś czas nadal w nim funkcjonowały. Autor mógł również użyć informacji o markach, które w świadomości społecznej pozostawały jeszcze wówczas lepiej rozpoznawalną jednostką monetarna.

${ }^{38}$ Jeszcze o spelunkach, „Polska Zbrojna” 1925, nr 40, s. 7. 
dodatkową opłatę. Wyjątkiem mieli być „nowicjusze”, których należało wciagnać $\mathrm{w}$ zabawę ${ }^{39}$. W trzecim z kolei reportażu poświęconym rozbitej szajce autor dodawał, że wokół głównych organizatorów całej akcji „kręciło się kilku drobniejszych przedsiębiorców” oraz że „rewizja dokonana w dniu 9 b.m. w mieszkaniu Zubrzyckiego dała bogaty materiał $\mathrm{w}$ postaci całych talii i zapasów pojedynczych kart, dokładanych do talii w miare potrzeby" ${ }^{40}$. Jak się okazało, cała akcja zorganizowana przez policję odbyła się za późno, przywódcy szajki mieli zbiec na Riwierę, jeden z nich wywiózł ponoć z Polski około 200 tys. dolarów ${ }^{41}$.

Ten, nieco zapewne ubarwiony, wieloodcinkowy reportaż ukazuje wyraźnie ówczesną specyfikę postrzegania tego typu przestępstw. Opisywanie miejsc, gdzie nielegalnie grano na pieniądze, czy działań policji, często traktowane było jako dobrze sprzedająca się sensacja. Niezmiernie rzadko starano się dostrzegać właściwy charakter problemu, jakim był nielegalny hazard i konsekwencje jego uprawiania. Hazardu nie traktowano tak do końca jako społecznie szkodliwej dziedziny życia. Osoby defraudujące fortuny czy popełniajace samobójstwa, a uzależnione od hazardu, traktowano jako „ciekawe zjawiska”, które należy piętnować, a nie współczuć. Hazard pozostawał przedmiotem fascynacji, symbolem lenistwa, demoralizacji, wyuzdania. Informacje o nielegalnych kasynach, które cieszyły się dużym zainteresowaniem wśród mniej wyrafinowanych czytelników, dawały im namiastkę „zgniłego moralnie", ale i fascynującego jednocześnie świata zachodniego. Można było z czystym sumieniem stwierdzić, co też często czyniono, że i w tej dziedzinie pozostajemy, czy raczej próbujemy pozostać, wśród państw cywilizacji zachodniej.

Najbezpieczniejszym miejscem do gry pozostawały prywatne mieszkania. W związku z tym właśnie $\mathrm{w}$ takich miejscach najczęściej nielegalnie uprawiano hazard, niekoniecznie w waskim gronie.

Potencjalni gracze mogli też wybierać pomiędzy, jak nazywała to policja, „lokalami luksusowymi”, zwykłymi mieszkaniami czy w końcu zapuszczonymi melinami. Warszawskiej policji udało się m.in. zlikwidować pokatne kasyna w „luksusowo urządzonych mieszkaniach” przy ul. Świętojerskiej ${ }^{42}$ (lokalizacja „luksusowego” lokalu na Starym Mieście może nieco zaskakiwać - ta część międzywojennej stolicy do luksusowych

${ }^{39}$ Tamże.

${ }^{40}$ Jeszcze o wykrytych szulerniach, „Polska Zbrojna” 1925, nr 41, s. 4.

${ }^{41}$ Tamże.

${ }^{42}$ AP m.st. Warszawy, KPP m.st. Warszawy, sygn. 374, Komunikaty sytuacyjne, 1937-1938, s. 211. 
wówczas nie należała), Dzielnej ${ }^{43}$ czy Wilczej $^{44}$. Ostatni z lokali należał, jak czytamy w policyjnym raporcie, do „kapitalistki” Marii T., a jednym z krupierów był, znany warszawskiej policji, Leopold O., który obok pełnienia obowiązków krupierskich prowadził również własny dom gry przy ul. Wojciecha Górskiego, zamknięty przez policję w styczniu 1938 r. ${ }^{45}$ Zdarzało się, że właścicielami lokali bywały kobiety i to niekoniecznie lokujące się na ekonomicznie i społecznie definiowalnym marginesie społecznym. W maju 1930 r. na ul. Koszykowej policja zlikwidowała kolejny lotny dom gry w ruletkę. Przy grze w ruletce policjanci zastali siedem osób, w banku znajdowało się 700 zł, a grających obsługiwała służąca właścicielki lokalu, hrabiny Ireny Mielżyńskiej ${ }^{46}$.

Nielegalne domy gry działajace w restauracjach, herbaciarniach czy kawiarniach stosunkowo łatwo były przez policję wykrywane i likwidowane, co sprawiało, że ich żywot pozostawał znacznie krótszy od tych, które działały w hotelach czy mieszkaniach prywatnych. Odwiedzało je wiele różnych osób, poza tym pozostawały miejscami, które z racji swojego przeznaczenia były częściej kontrolowane, zarówno przez służby sanitarne, jak i policję. Zdarzały się sytuacje, że działalność nielegalnego kasyna pozostawała „tajemnica poliszynela” i dopóki w okolicach lokalu nie dochodziło do burd, a goście zachowywali się spokojnie, policja nie interweniowała. Takie sytuacje dotyczyły przede wszystkim lokali o rzeczywistym statusie miejsc „luksusowych”, w których niejednokrotnie grywały osoby z ówczesnej elity. Nierzadko skorumpowani policjanci pilnowali bezpieczeństwa grających. Spotykamy więc w notatkach prasowych poświęconych zamykaniu domów gry informacje o lokalach działających „od pewnego czasu” lub „od dłuższego czasu”. Przypuszczać można, że zamykano je wówczas, kiedy fama o ich istnieniu roznosiła się zbyt szerokim echem. Z drugiej strony, częstotliwość otwierania lokali przez doskonale znane policji osoby, które prowadziły domy gry przez dłuższy czas, świadczyć może o uczestnictwie w tym procederze również, niewolnych przecież od pokus, funkcjonariuszy policji. Wiele, szczególnie podlejszej jakości „kasyn” stanowiło dla policji doskonałe miejsce do organizacji obław na przestępców, którzy tam grywali.

Nie zawsze bowiem likwidacja kasyna pozostawała głównym celem policyjnych nalotów. Wykrywano je i zamykano zazwyczaj przy okazji

\footnotetext{
${ }^{43}$ Tamże, s. 326.

${ }_{44}$ Tamże, s. 80.

45 Tamże, s. 335.

${ }^{46}$ Wykrycie lotnego domu gry, „Gazeta Warszawska” 1930, nr 129, s. 5.
} 
obław urządzanych na przestępców, którzy zwykli w tego typu lokalach spędzać wolny czas. W kwietniu 1939 r. ponownie we wspomnianym już barze „Wersal” przy ul. Elektoralnej zlikwidowano potajemny dom gry, gdzie zatrzymana została kilkudziesięcioosobowa grupa graczy, „rekrutująca się przeważnie z elementu przestępczego, karanego sadownie za oszustwa, kradzieże, komunizm, rozbój itp." ${ }^{47}$ Tym razem policji zależało na gościach lokalu.

Spotkać można jednak wyjątki, kiedy dom gry działał stosunkowo długo w lokalu gastronomicznym. 21 X 1936 r. w raporcie policyjnym czytamy, że funkcjonariuszom Urzędu Śledczego udało się zlikwidować jeden z największych, jak pisano, kantorów bukmacherskich w Warszawie, zorganizowany w „Cafe Smith” przy pl. Żelaznej Bramy $9^{48}$. Kantor zorganizował, przy współudziale właściciela kawiarni Wolfa Sz., Izrael R., zamieszkały przy ul. Krochmalnej ${ }^{49}$. W marcu 1937 r. w tym samym lokalu zlikwidowano tym razem „spelunkę różnych gier hazardowych", w której zatrzymano 13 grających w domino osób, jak dodawano, „z których kilku osobników [było] poszukiwanych przez władze sąowe" ${ }^{50}$. Ponownie funkcjonariusze warszawskiej policji zorganizowali tam nalot w grudniu 1938 r., tym razem udało się zatrzymać 40 osób grających w kiszkę ${ }^{51}$. W sprawozdaniu z akcji stwierdzono, że Wolf S. to „osobnik wielokrotnie notowany za opór policji i bookmacherstwo" 52 . „Cafe Smith”, choć notorycznie odwiedzane przez policję, świetnie funkcjonowało jako stały dom gry.

Wbrew oczekiwaniom prasy i złaknionej sensacji publiczności stołecznym nielegalnym „kasynom” daleko było do legendarnych domów gry w Monte Carlo. To, co często szumnie nazywano „kasynem”, było zazwyczaj podłej jakości lokalem czy melina, w których kilku, urozmaicających sobie wolne chwile, drobnych złodziei grało na pieniądze. W nocy z 4 na 5 VII 1936 r. policja zlikwidowała dom hazardowy przy ul. Bonifraterskiej 2, zorganizowany przez Szlamę P. W czasie „nalotu”, przy grze w kiszkę, zastano 36 osób, z których, jak donosił raport policyjny, prawie połowa okazała się być już wcześniej notowana ${ }^{53}$. Nie

${ }^{47}$ AP m.st. Warszawy, KPP m.st. Warszawy, sygn. 375, Komunikaty sytuacyjne, 1939, s. 126.

${ }^{48}$ Tamże, s. 254.

${ }^{49}$ Tamże.

${ }^{50}$ AP m.st. Warszawy, KPP m.st. Warszawy, sygn. 374, Komunikaty sytuacyjne, 1937-1938, s. 70.

${ }^{51}$ Tamże, s. 609.

52 Tamże.

${ }^{53}$ AP m.st. Warszawy, KPP m.st. Warszawy, sygn. 372, Zgłoszenia sytuacyjne, 1936, s. 161. 
był to jednak rekord. Gra ta gromadzić mogła znacznie więcej osób. W kawiarni Sany B. przy ul. Karmelickiej we wrześniu 1936 r. policja zastała przy grze w domino 80 osób ${ }^{54}$.

Nie ma, niestety, jak się wydaje, żadnych szans na to, by oszacować możliwe wpływy z prowadzenia pokątnej ruletki. Wysokość sum trafiających w ręce organizatorów zależała oczywiście od wielu czynników: lokalizacji, popularności, liczby zatrudnionych krupierów, ochrony, prostytutek, barmanów czy w końcu przekupionych policjantów oraz właścicieli lokali.

Zyski czerpane z organizacji nielegalnej ruletki nie musiały być wyjątkowo wysokie. W nocy z 2 na 3 XII 1926 r. na ul. Pawiej w mieszkaniu Neuhausa policja zlikwidowała lotny dom gry hazardowej w karty $^{55}$. Przy grze zatrzymano 32 osoby oraz skonfiskowano 308 kart. Notatka prasowa o Neuhausie brzmiała: „Właściciel mieszkania po odbyciu kary w więzieniu, ma jeszcze dwa wyroki za prowadzenie potajemnego domu gry. Ponieważ władze sądowe wymagały $1000 \mathrm{zł}$ kaucji, a Neuhaus zaś ich nie posiadał, osadzono go powtórnie w więzieniu" ${ }^{56}$. Wcześniej przyłapano go, również w jego mieszkaniu, w lutym 1925 r., kiedy zorganizował grę w karty dla 17 osób ${ }^{57}$. Oczywiście suma kaucji była bardzo wysoka i jej niewpłacenie nie musiało oznaczać, że Neuhaus był nędzarzem (równie prawdopodobne jest, że szkoda mu było pieniędzy). Wskazywałoby to jednak - nie wprost i niejednoznacznie - że często podawane przez prasę sumy wygranych czy zysków z nielegalnych kasyn były znacznie wygórowane, by nie rzec przesadzone.

Pewną wskazówką ułatwiająca określenie poziomu dochodowości hazardu były sumy, jakie w czasie nalotów policyjnych rekwirowano. Różnice były bardzo duże. W czasie organizowanych spontanicznie w lokalach gastronomicznych grach, np. w kiszkę, sumy były niewielkie, zazwyczaj kilka złotych. Inaczej niż w luksusowych domach gry, gdzie sięgały nawet setek tysięcy złotych! Tego typu sytuacje zdarzały się jednak wyjątkowo rzadko. Największą suma, z jaką spotkałem się w czasie badań było zarekwirowane w czasie nalotu 3 tys. zł. Najmniejsza, dodać należy dla porządku, wynosiła 17 zł.

${ }^{54}$ Tamże, s. 217.

${ }^{55}$ Wykrycie lotnego domu gry, „Kurier Warszawski” 1926, nr 332, s. 4.

56 Tamże.

${ }^{57}$ Wykrycie domu gry, „Nasz Przegląd” 1925, nr 55, s. 7; Dom gry, „Rzeczpospolita” 1925, nr 48, s. 6. 


\section{Środowisko organizatorów nielegalnego hazardu}

Nie sposób obliczyć, ile mogło działać w Warszawie nielegalnych domów gry czy kantorów bukmacherskich. Uczestnicy nielegalnie organizowanych gier często zmieniali lokale. W miejsce zamkniętego powstawał następny, nierzadko na tej samej ulicy. Nie ma też możliwości oszacowania, nawet w przybliżeniu, jak wiele osób brało udział w tym procederze. Mowa tu zarówno o graczach, jak i organizatorach, krupierach, porządkowych, damach do towarzystwa czy w końcu właścicielach lokali. Zachowane, szczątkowe dane policyjne nie daja podstaw do tworzenia całościowego obrazu. W 1933 r. statystyka policyjna dla Warszawy wykazywała, że w mieście działało 27 graczy szulerów (trudno jednoznacznie określić, czy chodziło o graczy, czy raczej organizatorów, a może, co wydaje się najbardziej prawdopodobne, o karcianych oszustów), w tym 14 katolików i 13 żydów ${ }^{58}$. Wśród całej grupy 16 osób skazanych było za nielegalny hazard tylko raz, 3 - dwa razy, 4 osoby trzykrotnie. Byli także gracze, którzy w ręce policji wpadli wcześniej po cztery, sześć, dziewięć, a nawet dwanaście razy ${ }^{59}$. Autor statystyki tak podsumowywał czesść dotycząca hazardu: „O graczach szulerach w Warszawie materiały śledcze są dopiero w opracowaniu, w tej chwili więc trudne jest omawianie stosunków na tym odcinku przestępczości"60. Materiały te, z wielu powodów, należy potraktować bardzo ostrożnie.

Organizatorami nielegalnego hazardu byli przede wszystkim Polacy i Żydzi, z nieznacznym wskazaniem na tych drugich ${ }^{61}$. Spotkać można było jednak również przedstawicieli innych narodowości. W styczniu 1934 r. w mieszkaniu Chany Mann na ul. Zielnej 27 dom gry zorganizował wraz z Polakiem Arslaud Tsinkliadze z Gruzji62.

Dysponujemy danymi ogólnopolskimi z lat 1924-1933, które dotycza liczby osób skazanych za hazard karciany w latach 1924-1929.

Dane przedstawione na rysunku dotyczą tylko organizatorów gier. Nie sposób niestety określić, jaki realny odsetek wszystkich organizatorów stanowili ci zatrzymani. Warto zwrócić uwagę, że w latach 1926-1927 średnio dziennie w Polsce skazywanych było prawie 6 osób za organizowanie gier hazardowych. Niemniej jednak skazani za ten rodzaj wykroczenia stanowili zaledwie ułamek procenta $\mathrm{w}$ stosunku

${ }^{58}$ A. Sitkowski, Statystyka przestępczości zawodowej na terenie Warszawy, „Archiwum Kryminologii” 1, 1933, z. 3-4, s. 500.

59 Tamże, s. 501.

60 Tamże, s. 503.

${ }^{61}$ Tamże, s. 226.

${ }^{62}$ Zlikwidowanie tajnego kasyna gry, „Gazeta Polska” 1934, nr 14, s. 12. 
do ogółu skazywanych za różnego rodzaju wykroczenia. Różnice w poszczególnych latach wiązać należy chyba z aktywnością działań policji i sądów, w jednych latach większa, w innych mniejsza. Wydaje się, że sytuacja gospodarcza w kraju nie wpływała znacząco na rozwój nielegalnego hazardu.

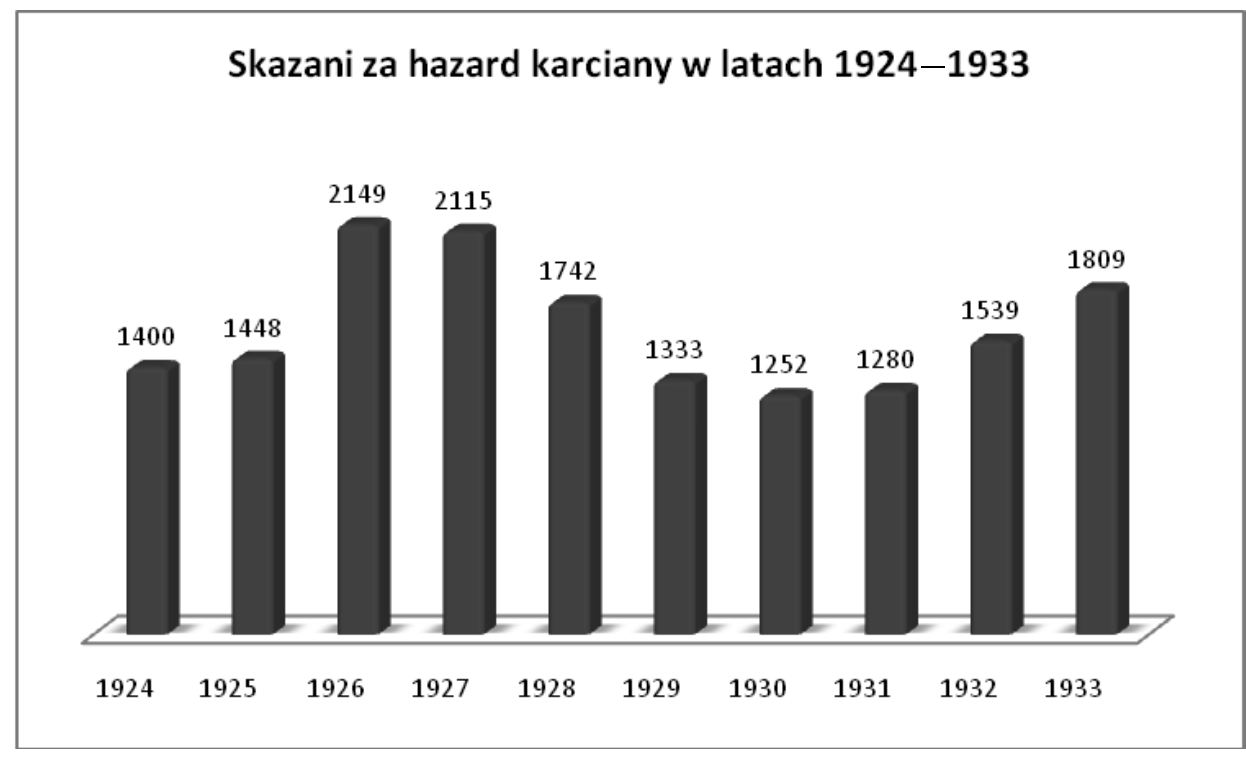

Źródło: L. Radzinowicz, Przestepczość w Polsce w latach 1924-1933 (według policyjnej statystyki kryminalnej), „Archiwum Kryminologiczne” 2, 1935, z. 1-2, s. 15.

Animatorzy nielegalnego podziemia hazardowego w Warszawie nie byli powszechnie znani, niemniej sylwetki kilku z nich można przybliżyć. W dokumentach policyjnych i na łamach gazet pojawiali się stosunkowo często: Aleksander W., Stanisław Bronza, Damazy S. oraz Stanisław Puchalski. O Aleksandrze W. w policyjnej charakterystyce można przeczytać: „złodziej, włamywacz, ruleciarz, utrzymuje się wyłącznie z przestępstwa, w lokalu jego organizowane są różne gry hazardowe" ${ }^{3}$. W marcu 1937 r. policji udało się zlikwidować bandę szulerów karcianych i organizatorów gier hazardowych, na czele której stał właśnie Aleksander W. Razem z przywódca szajki zatrzymano sześciu krupierów oraz „skonfiskowano ruletkę, sukna zielone z cyframi i inne przybory do gry w ruletkę, oraz kilkanaście talii do gry w kart”"64. Głów-

${ }^{63}$ AP m.st. Warszawy, KPP m.st. Warszawy, sygn. 401, Wnioski o osadzenie kryminalistów w miejscach odosobnienia, 1938-1939, s. 166.

${ }^{64}$ Tamże, sygn. 374, Komunikaty sytuacyjne, 1937-1938, s. 54. 
ny lokal, jeden z kilku, jakimi dysponowała grupa szulerów, znajdował się przy ul. Marszałkowskiej ${ }^{65}$. Również na tej ulicy, w kamienicy pod innym numerem, swoje własne kasyno prowadził Damazy S. Między innymi w styczniu 1938 r. zastano u niego 13 osób grajaccych w ruletkę ${ }^{66}$. Pół roku później ponownie znalazł się w rękach policji za zorganizowanie domu gry na ul. Leszno, gdzie udało mu się sprowadzić 10 miłośników hazardu. W czasie rewizji policja skonfiskowała m.in. „zupełnie nową olbrzymich rozmiarów ruletkę z kompletnym urządzeniem oraz gotówkę" ${ }^{67}$. Pierwszy znany nam dom gry zorganizowany przez Puchalskiego mieścił się przy ul. Kruczej 9 i grało w nim 6 osób ${ }^{68}$. Ponownie pojawił się on jako bohater opisanej wyżej afery z lotnymi domami gry w 1925 r. ${ }^{69}$ Po kilkuletniej przerwie kolejne kasyno otworzył w lokalu przy ul. Marszałkowskiej 31, gdzie po obławie stwierdzono, „że lokal należał do najbardziej luksusowych tego typu"70. Jeszcze w tym samym roku (1934), niecałe dwa miesiące później policja znów zlikwidowała zorganizowany przez Puchalskiego dom gry, mieszczący się również przy ul. Marszałkowskiej pod numerem $33^{71}$. Tym razem, jak donosiła gazeta, $\mathrm{w}$ „lokalu specjalnie przygotowanym do gry w ruletkę i posiadającym wszelkie urządzenia umożliwiające ukrycie «dowodów rzeczowych», do stolików zasiadły 22 osoby"72.

Jedna z najważniejszych postaci warszawskiego nielegalnego hazardu pozostawał Stanisław Bronz, który zajmował się organizowaniem w stolicy domów gry przez cały niemalże okres międzywojenny. Jak donosiła prasa, $10 \mathrm{~V} 1923 \mathrm{r}$. w hotelu przy ul. Koziej w pokoju nr 56, zajmowanym przez Stanisława Bronza, policja zastała 16 osób grajacych w pokera ${ }^{73}$. W notatce prasowej czytamy: „Na widok przedstawicieli władzy gracze zdążyli pieniądze ukryć. Karty w ilości dwóch talii, których część znajdowała się maszynce do rozdawania kart, zabrano jako dowód rzeczowy. Wszystkich graczy odprowadzono do komisariatu. Badany Bronz oświadczył, że zaprosił do siebie kolegów na ucztę imieninowa, którą odłożył z dnia św. Stanisława na noc z 9 na 10 b.m.”74 $\mathrm{W}$ połowie 1925 r. Bronz został przyłapany jako gracz w nielegalnym

\footnotetext{
${ }^{65}$ Tamże.

66 Tamże, s. 361.

${ }^{67}$ Tamże, s. 480.

${ }^{68}$ Potajemne kluby gry, „Nasz Przegląd” 1924, nr 5, s. 3.

${ }^{69}$ Zob. przyp. 63.

${ }^{70}$ Zlikwidowanie drugiego tajnego domu gry, „Gazeta Polska” 1934, nr 16, s. 10.

${ }^{71}$ Wykrycie tajnego domu gry, tamże, nr 54, s. 10.

72 Tamże.

${ }^{73}$ Wykrycie potajemnego domu gry, „Nasz Przegląd” 1923, nr 45, s. 3.

74 Szulernia w Hotelu Saskim, „Polska Zbrojna” 1923, nr 127, s. 4.
} 
kasynie mieszczącym się przy ul. Marszałkowskiej $62^{75}$. Osiem lat później, w 1933 r., został zatrzymany jako współorganizator ruleciarni w Al. Jerozolimskich 93, za co został skazany na 14 dni aresztu i 1500 zł grzywny ${ }^{76}$. Wówczas wraz z nim do aresztu powędrowały jeszcze dwie osoby. Następne kasyno Bronz zorganizował przy ul. Nowolipie 33 w mieszkaniu Dawida G., w grudniu 1935 r. ${ }^{77}$ Ponownie na jego ślad natrafić można w sprawozdaniach policyjnych z $1938 \mathrm{r}$. 25 lipca Bronz był organizatorem ruletki w mieszkaniu przy ul. Elektoralnej, grało tam tej nocy 14 osób. Nieco ponad miesiąc później (30 sierpnia) wpadł ponownie, tym razem w mieszkaniu przy ul. Muranowskiej ${ }^{78}$. Kolejna ruletę, zorganizowana przez niego już dwa tygodnie później, policja zlikwidowała tym razem przy ul. Śliskiej, gdzie grało 15 osób $^{79}$.

Przykład Stanisław Bronza, a postaci takich jak on było zapewne więcej, pokazuje, że działania ówczesnej policji trudno nazwać skutecznymi. Likwidacja jednego kasyna powodowała, że tydzień później, kiedy zatrzymany organizator wychodził z aresztu na wolność, w nowym mieszkaniu rozpoczynało działalność następne.

Organizatorzy domów gry bywali nierzadko jednocześnie właścicielami kantorów bukmacherskich. Wolf S. w swoim lokalu „Cafe Smith” oferował całą gamę rozrywek: od zakładów bukmacherskich, przez grę w karty, po ruletkę. Również Ryszard S. z ul. Żulińskiego, jak podawał raport policyjny, ,jest znanym bukmacherem i karciarzem, który tryb życia prowadzi rozrzutny. W domu jego bywają często awantury urządzane przez graczy na wyścigach, którym nie chce wypłacać wygranych na wyścigach" ${ }^{80}$. Notowany był m.in. w październiku 1932 r. za hazardowa grę w karty oraz w sierpniu 1935 r. za bukmacherstwo. Takich postaci było w ówczesnej Warszawie niewątpliwie znacznie więcej. W 1927 r. w „Robotniku” zamieszczono notatkę o akcji policjantów z XI komisariatu, którzy zlikwidowali na ul. Nowogrodzkiej 44 ,potajemny" dom gry w ruletkę ${ }^{81}$. Właścicielem nielegalnego kasyna był, znany m.in. z działalności bukmacherskiej, niejaki Dratwa ${ }^{82}$.

${ }^{75}$ Dom gry przy Marszatkowskiej, „Nasz Przegląd” 1925, nr 129, s. 7.

${ }^{76}$ Walka z domami gry hazardowej, „Gazeta Polska” 1933, nr 276, s. 10.

${ }^{77}$ Dom gry, „Kurier Warszawski” 1935, nr 332, s. 5.

${ }^{78}$ AP m.st. Warszawy, KPP m.st. Warszawy, sygn. 374, Komunikaty sytuacyjne, 1937-1938, s. 483, 512.

79 Tamże, s. 524.

${ }^{80}$ AP m.st. Warszawy, KPP m.st. Warszawy, sygn. 464, Informacje, opinie, wywiady oraz zapytania o karalność dotyczące różnych osób, 1938, s. 129.

${ }^{81}$ Wykrycie domu gry przy ul. Nowogrodzkiej, „Robotnik” 1926, nr 253, s. 4.

${ }^{82}$ Tamże. 
Bukmacherzy czy „właściciele” kasyn bywali również jednocześnie złodziejami, sutenerami czy paserami ${ }^{83}$. Zorganizowanie przenośnego kantoru przyjmującego zakłady traktowane bywało przez zawodowych przestępców jako dodatkowe, znacznie bezpieczniejsze źródło dochodów. Jak donosiła notatka policyjna, Szyja F. był notowany dwukrotnie za sutenerstwo (prowadził dom publiczny przy ul. Alberta) i organizowanie gier hazardowych. W dalszej części notatki czytamy: „F. jest zawodowym organizatorem gier niedozwolonych. Wynajmuje u przestępców mieszkania na uprawianie gier hazardowych w ruletkę. Ostatnio w dniu 1 marca 1938 r. został zatrzymany w Warszawie przy ul. Elektoralnej [...] u znanego przestępcy Abrama K. zam[ieszkałego] tamże, gdzie zakwestionowane zostały żetony i 257 zł gotówka" ${ }^{84}$. Tego typu przypadków było znacznie więcej. Miały jednak również miejsce sytuacje, w których organizatorami nielegalnych zakładów czy kasyn bywały osoby pozornie dalekie od marginesu społecznego. W maju $1937 \mathrm{r}$. przy ul. Fredry w prywatnym mieszkaniu zlikwidowano dom gry w ruletkę, gdzie „zakwestionowano dwie rulety z kompletnymi przyborami do gry"85. Organizatorem tego przedsięwzięcia był dwudziestotrzyletni... student prawa ${ }^{86}$. Wśród osób aranżujących działalność „kasyn” spotykamy również: fryzjerów, urzędników, handlarzy czy właścicieli restauracji.

Pomiędzy bukmacherami, podobnie jak i szulerami czy właścicielami nielegalnych kasyn, wielokrotnie dochodziło do konfliktów. Zazwyczaj ich powodem byli klienci, podbierani przez konkurencję, rzadziej kłócono się o np. lokale. W źródłach policyjnych nie udało się znaleźć przykładów tego typu zatargów. Najczęściej bowiem załatwiano je we własnym gronie, starając się, by policja nic o tym nie wiedziała. Niemniej jednak znajdowali się wśród bukmacherów także tacy o krewkim charakterze, którzy swoje problemy rozwiązywali pod wpływem chwili, ujawniając się w ten sposób opinii publicznej. W kwietniu 1929 r., w restauracji „Astoria” przy ul. Nowy Świat 66, bukmacher Władysław Mirski ugodził w ramię Ignacego Hoffmana - podejrzewanego o bukmacherstwo - nożem fińskim ${ }^{87}$. Jak donosiła „Gazeta Warszawska”,

${ }^{83}$ AP m.st. Warszawy, KPP m.st. Warszawy, sygn. 401, Wnioski o osadzenie kryminalistów w miejscach odosobnienia, 1938-1939, s. 473.

${ }^{84}$ Tamże, s. 164.

${ }^{85}$ AP m.st. Warszawy, KPP m.st. Warszawy, sygn. 374, Komunikaty sytuacyjne, 1937-1938, s. 107.

${ }^{86}$ Tamże.

${ }^{87}$ Krwawa rozprawa nożowa $w$ „Astorii”. Epilog nieporozumień między „bookmacherami” wyścigowymi, „Gazeta Warszawska” 1929, nr 149, s. 6. 
obydwaj panowie w obliczu nadchodzącej policji szybko doszli do porozumienia i pogodzili się.

\section{W szponach nałogu. Gracze}

Losy osób grajacych, w tym nałogowych hazardzistów, śledzić jest niezwykle trudno, nawet w Warszawie. W prasie pojawiały się co jakiś czas lakoniczne informacje o ofiarach hazardu, które bądź przegrywały zdefraudowane przez siebie pieniądze, bądź z powodu przegranej popełniały samobójstwo ${ }^{88}$. Tak np. w $1933 \mathrm{r}$. właściciel domu handlowego przy ul. Marszałkowskiej, Stanisław Finkler, „zwykle spokojny i zrównoważony, tu [w Sopocie] tracił panowanie nad soba, przegrywał, to znów wygrywał, w sumie jednak jego konto wykazywało wzrastający debet. Aż dnia pewnego z przerażeniem uświadomił sobie, że jest człowiekiem zrujnowanym". Chcąc spłacić swoje długi, sfałszował weksle na 500 tys. zł, co jeszcze bardziej skomplikowało jego sytuację. Rozwiązaniem problemu według hazardzisty-oszusta było - jak się okazuje samobójstwo ${ }^{89}$. Odbieranie sobie życia przez nałogowych hazardzistów często było głównym argumentem przeciwko wszelkim formom hazardu, szczególnie tym nielegalnym. Samobójstwo i hazard w świadomości społecznej funkcjonowały w pełnej symbiozie. Publicysta „Rzeczpospolitej" tak odpowiadał na pomysł otwarcia w Warszawie legalnego - co przecież było niemożliwe - domu gry: „Może uważaja, że Warszawa pozostaje w tyle za innymi miastami europejskimi pod względem ilości samobójstw i są zdania, iż funkcjonowanie ruletki może doskonale wpłynąć na wysunięcie się stolicy Polski na naczelne miejsce tej niewesołej statystyki. Wszystko jest możliwe, bo skoro autorzy podania moga szeroko rozwodzić się, że ruletka jest niewinną zabawką wobec totalizatora i na tej zasadzie domagaja się pozwolenia na swe przedsiębiorstwo, to mogą wysuwać również inne a równie rozsądne argumenty ad hoc ukryte" ${ }^{90}$.

${ }^{88}$ Defraudacja, „Kurier Warszawski” 1935, nr 293, s. 6: „Hurtownicy mięsni Robin (Złota 40) i Feldman (Bagno 3) zameldowali w Policji, że ich inkasent Abram Kueberg (Pańska 20) zdefraudował 4000 zł, ściagnięty do badania K. twierdzi, że wcale nie zdefraudował pieniędzy, tylko je przegrał na wyścigach. K. grał nie na własny rachunek, tylko na ryzyko swoich pryncypałów, którzy uważali go za fachowego znawcę koni. Trochę się nie powiodło, ale przy większej cierpliwości - można by się odegrać. Sędzia śledczy nie brał bajeczek Kueberga na serio i kazał go osadzić w areszcie”.

${ }^{99}$ Jeszcze jedna ofiara jaskini gry w Sopotach, „Gazeta Polska” 1933, nr 239, s. 10.

${ }^{90}$ Kasyno gry... w podziemiach! Chca „uszczęśliwič” Warszawę ruleta, „Rzeczpospolita" 1929 , nr 179, s. 5 . 
Nierzadko chroniąc się przed konsekwencją swojej nieroztropności, symulowano napady, w czasie których zrabowane miały być - przegrane tak naprawdę - pieniądze. 27 II 1939 r. Tadeusz K. zgłosił na policji, że zrabowano mu 14 tys. zł „po uprzednim uderzeniu go twardym narzędziem w głowę i twarz - ustalono dochodzeniem, że wymieniony pieniądze przywłaszczył i przegrał w ruletkę do czego się przyznał w czasie przesłuchania"91. Pytanie, na które odpowiedzi zapewne nie znajdziemy, jak wielu klientów nielegalnych domów gry czy przygodnie organizowanych kantorów bukmacherskich nie tylko należało do świata przestępczego, ale stało się niewolnikami nałogu. Choć dopiero w obecnych czasach mamy do czynienia z profesjonalną pomoca dla osób uzależnionych od hazardu, pierwszy krok w tym kierunku uczyniono już wówczas.

W tym miejscu wspomnieć należy, że międzywojenne ustawodawstwo polskie przewidywało możliwość udzielenia pomocy osobom uzależnionym od hazardu oraz ich rodzinom. Przejawem działalności państwowej w ramach opieki nad osobami uzależnionymi od hazardu były sformułowania niektórych z paragrafów z rozporządzenia Prezydenta RP z 14 X 1927 r. o zwalczaniu żebractwa i włóczęgostwa. Artykuł 4 brzmiał: „Postanowienia niniejszego Rozporządzenia stosuje się również do tego: a) kto nałogowo oddając się grze hazardowej, pijaństwu, ostremu narkotyzowaniu się, dochodzi do takiego stanu, iż dla utrzymania bądź jego samego, bądź tych, których obowiązany jest żywić, udzielić trzeba pomocy z tytułu opieki społecznej"92. Osoby uzależnione od hazardu, choć definicyjnie nie mieściły się w pojęciach: „żebrak” i/lub „włóczęga”, przez ówczesnych urzędników Ministerstwa Pracy i Opieki Społecznej zostały zaliczone do grupy „zawodowych próżniaków”. W uzasadnieniu projektu, a konkretnie art. 4, ustawodawca tak tłumaczył motywy podjęcia swojej decyzji: „Art. 2, 3 i 4 obejmuja kategorie osób podlegających postanowieniu ustawy, przy czym art. 4 zostały objęte te kategorie osób, które jakkolwiek nie sa w ścisłym znaczeniu żebrakami lub włóczęgami, to jednak motywy ich postępowania sa analogiczne do motywów postępowania żebraków i włóczęgów"93. Formą opieki społecznej wyznaczona przez to rozporządzenie w stosunku m.in. do osób uzależnionych od hazardu było umieszczenie w tzw. domu pracy przymusowej. W sytuacji, kiedy nałogowy hazardzista trafiłby do domu pracy przymusowej, jego rodzina miała zostać objęta

${ }^{91}$ AP m.st. Warszawy, KPP m.st. Warszawy, sygn. 375, Komunikaty sytuacyjne, 1939, s. 156.

${ }^{92}$ Dz. U. 1927, nr 92, poz. 823.

${ }^{93}$ AAN, MSW, sygn. 520, Projekty ustawodawcze Ministerstwa Pracy i Opieki Społecznej [1924-1927], s. 18. 
opieka przez lokalne władze samorządowe. Takie postawienie problemu sytuowało hazardzistów wśród osób zdegenerowanych, których źródła nieszczęścia poszukiwano w ich wstręcie do pracy. Krótko mówiąc, osoba uzależniona od grania nie była, tak jak obecnie, uznawana za chora, ale za leniwa, która nałogowo oddaje się hazardowi. Stwierdzono więc, że najlepszą metodą na przywrócenie hazardzisty społeczeństwu będzie praca przymusowa.

Kim więc byli ludzie odwiedzający nielegalne kasyna? Ówczesna prasa $\mathrm{z}$ reguły wymieniała imiona i nazwiska oraz adresy przyłapanych przez policję graczy. Rzadko, co w żaden sposób nie uprawomocnia do wyciagania jakichkolwiek wniosków, podawano również ich zawody. I tak np. w styczniu i lutym w „Gazecie Polskiej” znaleźć można informację, że domu gry przy ul. Nowogrodzkiej 39 grali: dwaj krawcy, trzech kupców, kuśnierz, elektrotechnik i magister prawa ${ }^{94}$. W „kasynie" przy ul. Marszałkowskiej 95 do wspólnej gry zasiedli zaś: urzędnik, inżynier, ziemianin, szewc, przedsiębiorca przewozowy, bezrobotny, student, kancelista, murarz, dwóch kuśnierzy ${ }^{95}$. Te, nieweryfikowalne niestety dane, potwierdzają niejako, że hazard łączył ludzi pochodzących z wszystkich możliwych warstw społecznych. W najpodlejszych „spelunach” przebywali przede wszystkim przestępcy, którzy - jak twierdził jeden z ówczesnych kryminologów, Witold Świda - spędzać mieli cały swój wolny czas na zabawie z prostytutkami i grze w karty. Jeden z przestępców, z którym Świda rozmawiał, przyznać miał, że „na wolności złodzieje siedzą w truszczobach, herbaciarniach, gdzie pija wódkę, grają w karty i hulają z dziewczynami. Gdy kto z nich zarobi, to zaraz te pieniądze puści. Nieraz bywa, że przegrawszy wszystko w karty, wyjdzie na chwilę, aby coś skraść i wraca ze skradzionymi rzeczami, żeby dalej grać" ${ }^{\prime}$. Hazard, na nieco skromniejszą skalę i rzadko na pieniądze, pozostawał również często jedyną rozrywką skazanych odsiadujących kary w więzieniu. Między innymi jeden z odsiadujących wyrok w więzieniu mokotowskim został umieszczony w grudniu $1929 \mathrm{r}$. $\mathrm{w}$ karcerze na trzy dni za granie w karty w celi ${ }^{97}$. W październiku 1932 r. tamtejszy strażnik w skonfiskował grającym w celi nr 27 więźniom znajdujące się w „banku” 32 paczki papierosów i 50 gramów tytoniu ${ }^{98}$.

${ }^{94}$ Wykrycie domu gry $w$ ruletke, „Gazeta Polska” 1934, nr 20, s. 10.

${ }^{95}$ Likwidacja potajemnych domów gry, tamże, nr 30, s. 12.

${ }^{96}$ W. Świda, Przestepca zawodowy, Wilno 1932, s. 22.

${ }^{97}$ AP m.st. Warszawy, Więzienie Karne „Mokotów-Warszawa”, sygn. 1628, Akta dotyczące korespondencji ogólnej w sprawach więźniów, 1929.

${ }_{98}$ Tamże, sygn. 1727, Korespondencja z prokuratorem i innymi więzieniami w sprawach personalnych więźniów 1932 r., s. 569. 
Nieco ponad miesiąc później w tej samej celi skonfiskowano tym razem 15 paczek papierosów ${ }^{99}$.

Podkreślić należy również fakt, że w warszawskich szulerniach do wspólnej gry zasiadali zarówno Polacy, jak i Żydzi. Wyjątkowym zjawiskiem były lokale, w których nie spotykamy przedstawicieli obydwu narodowości. Miłość do hazardu okazywała się więc być silniejsza niż narodowe uprzedzenia, które tak silnie obecne były w życiu społecznym okresu międzywojennego.

Warto w tym miejscu wspomnieć, że karty książek Tadeusza Dołęgi-Mostowicza czy Sergiusza Piaseckiego zapełniaja postacie, różnej konduity, które namiętnie grywały w karty na pieniądze. Bohaterowie Kochanka wielkiej niedźwiedzicy praktycznie wszystkie wolne chwile spędzali na grze. W czasie jednego z postojów jeden z przemytników: „Szczur dostał z kieszeni talię kart i zaproponował zagrać w 66. Buldog rozesłał na sianie, podszewką do góry, swoją kurtkę i zaczęli grać na niej w karty. Dołączyli się do nich Mamut i Wańka Bolszewik"100. Wśród znajomych głównego bohatera cytowanej powieści Piaseckiego znajdujemy zarówno nałogowych graczy: „Saszka zarabiał nieraz duże pieniądze. Lecz z taką zapamiętałością je rozrzucał, że wkrótce znów nic nie miał. Nikt tak nie grał w karty jak on! Nikt nie rzucał tyle pieniędzy kobietom. Nikt tyle nie przepijał"101, jak i zawodowych szulerów: „Od Józefa Trofidy się dowiedziałem, że to jest zawodowy złodziej. Był niegdyś słynnym złodziejem - rzekł Józiek - lecz ożenił się z miłości i skrócił się. Po większej części gra w karty. Jest styrocznikiem”102. Również jeden ze znajomych głównego bohatera książki Żywot człowieka rozbrojonego - Kolka - zwierzał się: „Czułem się marnie, bo mam dużo kłopotów. Zgrałem się w karty, zadłużyłem. Teraz nie mogę dać sobie rady. Szukam innych szans, ale nie wiedzie mi się. Teraz gram tanio u Zielonego Sztralla albo w innych lokalach"103.

Doktor Murek z książek Dołegi-Mostowicza, przebywając przez jakiś czas w jednej z warszawskich noclegowni dla bezdomnych, obserwował, jak inni współlokatorzy każdą wolną chwilę spędzali, pijąc alkohol i grając w karty. Zwyczajowo więc wieczór w noclegowni wyglądał następująco: „Na narze przy wypróżnionych flaszkach zrobiło się pusto. Reszta towarzystwa rozlazła się po kątach. Na górze niektórzy już chrapali, inni rżnęli w «oko» i dolatywał stamtąd tylko tłusty odgłos przybijanych

\footnotetext{
99 Tamże, s. 664.

${ }^{100}$ S. Piasecki, Kochanek wielkiej niedźwiedzicy, Warszawa 2002, s. 34.

101 Tamże, s. 35.

102 Tamże, s. 37.

${ }^{103}$ Tenże, Żywot człowieka rozbrojonego, Warszawa 1990, s. 127.
} 
kart, przy drzwiach do umywalni awanturniczy Leonek wywołał bójkę". I dalej, już późnym wieczorem: „W kącie cichutko grał na organkach dziobaty Stasiek. Pod lampa jeszcze kilku namiętniejszych graczy kłóciło się o rzekomo znaczone karty, z różnych stron dolatywało chrapanie"104.

Słabość do gier hazardowych nieobca była także tym, którzy stać mieli na straży prawa. Poważne kłopoty z utrzymaniem dyscypliny wśród swoich podwładnych miał komendant stołecznej policji, szczególnie z tymi, którzy pełnili służbę na torach wyścigów konnych. Przez cały okres międzywojenny ponawiane były, bezskutecznie, próby odzwyczajania funkcjonariuszy policji od grania na wyścigach w czasie pełnienia służby. We wrześniu 1919 r. komendant uznał, że policjanci obstawiający gonitwy „wywierali niekorzystne wrażenie, biorąc pod uwagę nieznaczne wynagrodzenie funkcjonariuszów policji w stosunku do stawek totalizatorowych"105. Prawie 20 lat później, w kwietniu 1938 r., w jednym z rozkazów komendant Policji Państwowej w Warszawie pisał: „Doszło do mej wiadomości, że szeregowi policji uczęszczają na plac wyścigów konnych, gdzie w sposób hazardowy uprawiaja grę $\mathrm{w}$ totalizatora, przy czym dla łatwiejszego ominięcia ewentualnej kontroli przebieraja się po cywilnemu, względnie na mundury narzucaja cywilne okrycia"106. Przypominał jednocześnie swój rozkaz z 1935 r., dotyczący zakazu gry w totalizatorze przez policjantów, zarówno w mundurze, jak i w ubraniach cywilnych. Dowiadujemy się również, że powszechnym, zdaniem komendanta, procederem było odwiedzanie wyścigów konnych przez funkcjonariuszy będących po służbie ${ }^{107}$.

Również w Wojsku Polskim dość często zdarzały się osoby uprawiające hazard, w sytuacji kiedy żołnierzom nie wolno było tego robić. Oficerowie, podoficerowie i szeregowi wykazujący słabość do gier hazardowych mogli ponieść konsekwencje, nie tylko odpowiadając za złamanie prawa przed sądem, ale również zostać skreślonym z listy oficerów lub - w przypadku szeregowych - wyrzuconym z wojska. Problem jednak istniał. Świadczy o tym m.in. bezwzględny zakaz odwiedzania przez żołnierzy WP sopockiego kasyna ${ }^{108}$. Zagadnienie to, tylko sygnalizowane, wymaga jednak odrębnego opracowania.

${ }_{104}$ T. Dołega-Mostowicz, Doktor Murek zredukowany, Warszawa 2010.

${ }^{105}$ AP m.st. Warszawy, KPP m.st. Warszawy, sygn. 7, Rozkazy Komendanta PP m.st. Warszawy od nr 1031 do 1107, 1919, s. 47.

106 Tamże, sygn. 36, Rozkazy Komendanta PP m.st. Warszawy od nr 1286 do 1322, 1938, s. 30.

107 Tamże.

${ }^{108}$ Almanach oficerski na rok 1923/1924, red. K. Frich, S. Krzysik, T. Kutrzeba, S. Muller, J. Wiatr, Warszawa 1923. 
Najtrudniejszą i chyba niemożliwą wydaje się próba odtworzenia specyficznej atmosfery międzywojennych podrzędnych szulerni czy ekskluzywnych „kasyn”, do których zaproszenie dostawali tylko wybrani. Pewną szansę na jej poznanie pozostaje dalece niewygodne dla historyków źródło, jakim jest literatura piękna. Czytając prace cytowanego już wyżej Sergiusza Piaseckiego, przenosimy się do wielu opisywanych przez niego melin przestępczych, w których zawodowi przestępcy namiętnie grywali w karty. Na kartach Kochanka wielkiej niedźwiedzicy czytamy: „W pokoju było pełno wrzawy. Pijatyka szła w najlepsze. [...] Obejrzałem pokój, szukając Szczura. Zobaczyłem go na drugim końcu stołu, w pobliżu Alińczuków. [...] Zbliżyłem się do grających. Alfred Alińczuk trzymał bank. Wyją z kieszeni dwie talie nowych kart. Rozdarł opaski. Przetasował karty i położył 200 rubli. - W banki 200! - rzekł do grających. Zaczął rozdawać karty. Ja również wziąłem kartę. Pierwszy grał Szczur. - Daj za 50!"109 Również bohaterowie książek Dołęgi-Mostowicza nie stronia od kart. Znacznie rzadziej, by nie powiedzieć w ogóle, daje nam szansę literatura piękna zajrzeć do ekskluzywnych nielegalnych stołecznych kasyn. W dość słabym literacko utworze Stanisława Dzikowskiego pt. Gracz główny bohater, Jan Orda, nałogowy hazardzista, swoją ostatnia grę odbył w następujących okolicznościach: „torowali sobie drogę, wolno w kierunku bufetu, za którym znikała raz po raz jakaś postać. Jegomość w czarnym surducie zagrodził im drogę. - Panowie sobie życzą? Orda wysuną się naprzód i krzykną głosem ostrym, rozkazującym. - gdzie tu jest złoty stół? Bezczelną gębę rozjaśnił służalczy uśmiech: - Proszę, służę panom dziedzicom, właśnie panowie czekaja. Zapuścili się w wąski, długi korytarz. Wszędzie widniały małżeńskie, na półukryte drzwiczki, z poza których dobywało się już charakterystyczne wrzenie gry. Dopiero na końcu kryła się mała, zaciszna salka. Sześć głów schylonych podniosło się razem. Sześć par oczu przeszyło ich badawczo. Orda spojrzał i zobaczył, że nie ma nikogo znajomego"110. Orda odwiedza luksusowe domy, w których grywa $\mathrm{w}$ karty z innymi nałogowymi hazardzistami, pełniącymi ważne funkcje społeczne - pełno wokół niego dyrektorów, ministrów, wiceministrów, palących drogie cygara, pijących drogie trunki i zgrywajacych się do ostatniej nitki. To jedyna pozycja literacka, w której tak często przychodzi nam przemierzać luksusowe lokale. Niech więc niedostateczna ilość cytatów, które mogłyby wprowadzić nas w świat hazardu przeznaczonego dla wyższych sfer, stanie się zachętą dla badaczy, którzy - na

${ }^{109}$ S. Piasecki, Kochanek wielkiej niedźwiedzicy..., s. 76.

${ }^{110}$ S. Dzikowski, Gracz, Warszawa 1924, s. 152. 
co autor liczy - cytaty takie odnajdą i zamieszczą w swoich pracach poświęconych poruszanym tu zagadnieniom.

Kończąc niejako ten wątek, wspomnieć należy, że namiętnych graczy spotkać można było również wśród reprezentantów ówczesnych elit. Między innymi, jak wspomina Irena Krzywicka, co zresztą nie było tajemnica, nałogowym hazardzistą był Tadeusz Boy-Żeleński. Krzywicka pisała: „Jeżeli rżnął w karty z (bardzo przejściowej) namiętności dlatego, że kochanki jego, zwłaszcza Dagny, miały duże wymagania, więc zaloty światowe młodzieńca były kosztowne"111. Zreszta sam Boy - jak napisał Józef Hen - spowiadał się ze swojego nałogu, pisząc: „Skazany na obkuwanie podręczników medycyny, od których myśl mi uciekała, a broniąc się przed oblegającymi mnie zainteresowaniami umysłowymi [...] nie umiałem znaleźć innego rozwiązania, jak tylko chowając głowę jak struś... do domów gry"112. Hen cytuje również wspomnienia Boya-hazardzisty o przeżyciach, wręcz mistycznych, których doświadczaja gracze. Oddajmy jeszcze raz głos Boyowi, który pisał o grze w bakarata: „Chwila wahania, lekkie ciareczki przebiegają ci przez krzyże, wreszcie kupujesz. Teraz «filujesz». Jeśli jest jakaś przyjemność, która szatan wymyślił osobiście, to owa aż do bólu mocna rozkosz «filowania». Wysuwają się dwa rożki, potem nic, długo nic, biała płaszczyzna niemal aż do środka. Na tym milimetrze, który odsłoni się za chwilę, skupia się twoja myśl, nadzieja, duma; jeśli się okaże czwórka, jesteś bohaterem, bogiem, jeśli piątka - durniem. Czwórka! Oddychasz..." ${ }^{113}$. Szczęśliwie udało się Boyowi z nałogiem wygrać.

$$
* * *
$$

Próba odpowiedzi na wszystkie pytania, które dotyczyć mogą szeroko rozumianego zjawiska nielegalnego hazardu w okresie międzywojennym wykracza daleko poza ramy jednego artykułu. Wśród wielu zagadnień, które powinny stać się przedmiotem przyszłych badań, pozostaje m.in. problem międzydzielnicowych (międzyzaborowych) różnic, które być może miały wpływ na takie elementy jak częstotliwość uprawiania konkretnych form hazardu, skala zjawiska, miejsce jego występowania, społecznej oceny itd. We wstępie do artykułu zaznaczono, że u zarania II Rzeczypospolitej nielegalny hazard traktowany

${ }^{111}$ I. Krzywicka, Wyznania gorszycielki, oprac. A. Tuszyńska, Warszawa 2002, s. 253.

${ }^{112}$ Cyt. za: J. Hen, Błazen - wielki maż. Opowieść o Tadeuszu Boyu-Żeleńskim, Warszawa 1998, s. 48.

${ }^{113}$ Tamże, s. 49. 
był na terenach trzech byłych zaborów dość podobnie. Niemniej jednak pytaniem otwartym pozostaje kwestia, czy pomimo tego analizowane tu zjawisko miało jakieś cechy wyjątkowe $\mathrm{w}$ każdym $\mathrm{z}$ tych trzech rejonów II RP, a jeśli tak, to w jakim stopniu i zakresie różnice te można wyodrębnić. Interesujące wnioski moga również przynieść inne porównania. Mowa tu przede wszystkim o próbie zestawienia zjawiska hazardu w Warszawie i na wsi czy w ogóle na szeroko pojętej prowincji.

Oddzielne rozważania należałoby również poświęcić na szczegółową analizę języka (dyskursu), który służył w II RP do opisywania zjawiska nielegalnego, ale nie tylko, hazardu. Szczególną uwagę warto zwrócić chociażby na formy przekazu prasowego czy treści zawarte $\mathrm{np}$. w podręcznikach policyjnych, w których prezentowano m.in. instrukcje postępowania podczas likwidacji domów gry. Podręczniki te sa jednocześnie niezwykle ciekawym przykładem różnych sposobów pisania o hazardzie, organizatorach oraz graczach. Opisy środowiska związanego $\mathrm{z}$ hazardem pełne sa bowiem zarówno stereotypów na jego temat, jak i wniosków wynikającej z praktyki policyjnej. Ta swoista mieszanka wiedzy i klisz stanowi niezwykle ciekawy materiał do pogłębionych badań.

Interesujące wyniki mogłyby przynieść również badania oparte na szczegółowej analizie dokumentacji sądowo-policyjnej, nie tylko tej zachowanej dla Warszawy, których efektem stałby się obraz środowisk związanych z nielegalnym hazardem, zarówno organizatorów, jak i przede wszystkim graczy. W niniejszym artykule problematyka ta została już, w dalece niewystarczajacy jednak sposób, zasygnalizowana. Środowisko osób grajacych, zarówno regularnie, jak i okazjonalnie, to - z powodu braku źródeł - niepoliczalna niestety zbiorowość, w której można znaleźć przedstawicieli wszystkich ówczesnych grup społecznych, zbratanych miłością do gry. Szczególnie istotnym zagadnieniem podczas rekonstrukcji obrazu społeczności osób grających, przede wszystkim oszustów oraz nałogowych hazardzistów, jest zjawisko ich - dobrowolnych bądź wymuszanych - peregrynacji po kraju. W wielu sytuacjach, kiedy brakowało chętnych do gry w jednym mieście lub jeśli naloty policyjne stawały się zbyt uciążliwe, gracze czy oszuści zmieniali miejsce działania. W listopadzie 1917 r. w Lublinie aresztowano za hazardową grę w karty, uprawianą w bożnicy, Szlomę G., który za to samo był już kilkakrotnie karany wcześniej w Warszawie ${ }^{114}$.

${ }^{114}$ AP w Lublinie, Komenda Powiatowa Policji Państwowej w Lublinie, sygn. 68, s. 130. 
Przestępcy - oszuści i nałogowi hazardziści - wiedzieli, gdzie szukać okazji, by zagrać i zabawić się. Jak się okazuje, w Warszawie nie było to zadanie wyjątkowo trudne. Analiza tego środowiska w skali całego kraju pozwoliłaby m.in. zweryfikować także i tę tezę. Niewątpliwie już sama próba opisu wyłącznie grupy przestępczej, jaką byli - przede wszystkim karciani - oszuści, wydaje się nad wyraz ciekawą przygodą badawcza.

Mateusz Rodak

Illegal Gambling in the Second Republic of Poland

A Research Reconnaissance

(Summary)

The article is an attempt at presenting widely comprehended illegal gambling in the Second Republic of Poland (i.e. such games as roulette, poker or craps in which the outcome depends in sheer luck and not the players' skills), with consideration for its multi-aspect character. The text is a research reconnaissance limited to the area of pre-war Warsaw. The author treats illegal gambling in the Polish capital as a point of departure for general theses on the subject, referring to urban centres across the whole country to indicate those features of pre-war illegal gambling, which remained typical for Warsaw. The article is based on such sources as the local press and police-court-prison documentation as well as associated normative acts. Illegal gambling is discussed on several levels, first and foremost, its legal situation in the Republic, followed by its assorted forms and organisation, and, finally, the environment of its organisers and participants.

Mateusz Rodak - Instytut Historii PAN; e-mail: mateuszrodak@yahoo.pl 